\section{Summary}

Three cases of infective endocarditis occurring in patients with hypertrophic obstructive cardiomyopathy are described. One of these patients died as a result of a ruptured mycotic aneurysm. An analysis of the current literature with particular reference to the site, the precipitating causes, and the type of infecting organism in this condition is presented. It appears that the site of predilection of the infection may be the mitral valve. The commonest recognized organism remains Streptococcus viridans. The need for vigilance and adequate prophylactic precautions is stressed.

We are grateful to Dr. Samuel Oram for kindly referring Case 1, to Dr. Keith Ball for Case 3, and to Dr. E. Braunwald for kind permission to quote from his paper as yet to be published. We are also grateful to Professor J. F. Goodwin for allowing us to report Case 2. We wish to thank Professor V. Logue, of the National Hospital for Nervous Diseases, for permission to use his operative notes, as well as Dr. R. O. Barnard, National Hospital for Nervous Diseases, and Dr. E. G. J. Olsen, Hammersmith Hospital, for their histological reports. We also thank the departments of radiology and photography at Hammersmith Hospital.

\section{REFERENCES}

Boiteau, G. M., and Allenstein, B. J. (1961). Amer. F. Cardiol., 8, 614. Frank, S., and Braunwald, E. (1968). Idiopathic Hypertrophic Subacute Stenosis. A clinical analysis of 126 patients, with emphasis on the natural history. To be published.

Linhart, J. W., and Taylor, W. J. (1966). Circulation, 34, 595.

Oakley, C. M., Raftery, E. B., Brockington, I. F., Steiner, R. E., and Goodwin, J. F. (1967). Brit. Heart Ұ., 49, 629.

Rodbard, S. (1963). Circulation, 27, 18.

Soulie, P., Joly, F., and Carlotti, J. (1962). Acta cardiol. (Brux.), 17, 335.

\title{
Recovery from Acute Renal Failure Due to "Irreversible" Glomerular Disease*
}

\author{
PETER RICHARDS, † PH.D., M.B., M.R.C.P. ; D. J. EVANS, M.B. ; O. M. WRONG, D.M., F.R.C.P.
}

[With Special Plate facing Page 467]

Brit. med. F., 1968, 2, 459-462

Patients with acute glomerular disease who develop sufficient uraemia to require dialysis rarely recover, particularly if there are fibrinoid necrosis of glomerular capillaries and obliteration of Bowman's space by epithelial crescents, and especially if the patient is an adult (Merrill, 1957 ; Brun et al., 1958; Hutt et al., 1958 ; Alwall et al., 1958 ; Parsons and McCracken, 1959 ; Schreiner, 1960 ; Berlyne and Baker, 1964 ; Harrison ot al., 1964 ; Lee et al., 1966 ; Forland et al., 1966). But recovery is not so uncommon as to justify the opinion, which prevails in most renal units, that prolonged oliguria and biopsy evidence of severe proliferative glomerulonephritis indicate irreversible disease with an inevitably fatal outcome which does not merit repeated dialysis.

In our opinion it is often unwise to abandon hope for a useful recovery of renal function on the grounds that the histological lesions in a renal biopsy specimen appear to be severe and irreversible, and in support of this view we report here the clinical course and renal histology of four patients.

\section{Case 1}

A 14-year-old schoolboy developed oedema of the face, pain in the ankles and elbows, and generalized abdominal tenderness with diarrhoea on 15 February 1963, the day after the onset of a sore throat and cervical lymphadenopathy. On the third day of his illness he was admitted to another hospital, where the blood urea was found to be $130 \mathrm{mg} . / 100 \mathrm{ml}$. He passed no urine at that hospital and was transferred to Hammersmith Hospital on 21 February, at which time his blood pressure was $120 / 70$ and there was slight acral oedema. The haemoglobin was $11.3 \mathrm{~g} . / 100 \mathrm{ml}$; the plasma electrolyte concentrations were sodium 128 , potassium 6.6 , chloride 88 , and bicarbonate $15 \mathrm{mEq} / \mathrm{l}$; and the blood urea was $385 \mathrm{mg} . /$ $100 \mathrm{ml}$. The plasma globulin was increased to $4.5 \mathrm{~g} . / 100 \mathrm{ml}$., largely as a result of an increase in $\gamma$-globulin, and the plasma albumin was $2.8 \mathrm{~g} . / 100 \mathrm{ml}$. The antistreptolysin titre was 800 Todd units/ml. (normal less than 200 units/ml.) and there was a marked reduction in serum complement.

\footnotetext{
* Departments of Medicine and Pathology, Royal Postgraduate Medical School, London $\mathbb{W} 12$

† Now at St. Mary's Hospital Medical School, London W.2.
}

Five haemodialyses were required before the blood urea concentration ceased to rise (Fig. 1). Prednisolone $60 \mathrm{mg}$. daily was given from 15 March and was reduced to $20 \mathrm{mg}$. daily by 17 April, when he left Hammersmith Hospital. A percutaneous renal biopsy on 18 March showed six severely affected glomeruli, all with proliferative and exudative changes (Special Plate, Fig. 1). A crescent was present in one glomerulus and fibrinoid necrosis in another, two arterioles showed fibrinoid necrosis, and in one there was an associated polymorph reaction in the wall. In the less affected glomeruli the lesion appeared to be focal. Tubular atrophy was markedsome residual tubules were dilated and contained blood and protein casts. There was interstitial fibrosis with foci of plasma cells, eosinophils, and polymorphs. The histological diagnosis was acute glomerulonephritis, perhaps as a manifestation of polyarteritis.

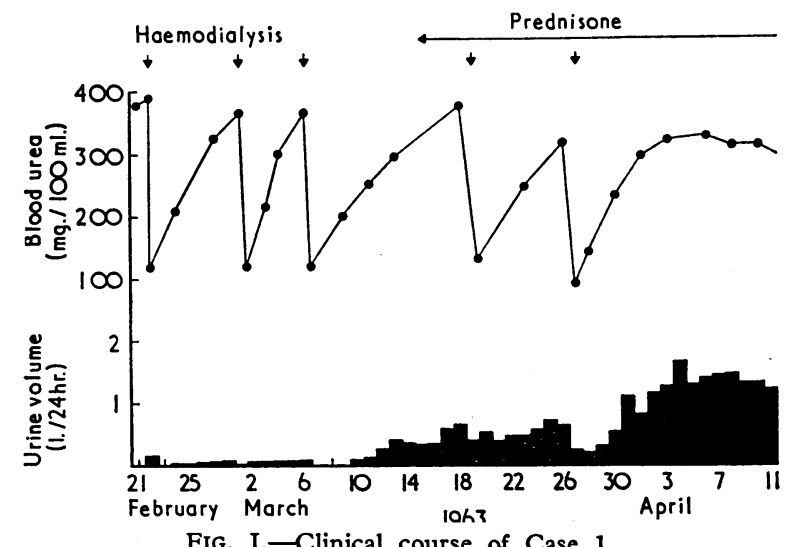

For 28 days the daily urine output never exceeded $400 \mathrm{ml}$. When haemodialysis was no longer required for the control of uraemia he became hypertensive. After he was discharged back to the referring hospital he made a very slow recovery and was not finally discharged home until December 1963. Treatment with prednisone was continued fo a further three months. In June 1964 the blood pressure was $130 / 90$ with treatment, the blood urea was $65 \mathrm{mg}$./ $100 \mathrm{ml}$., and the serum proteins were normal ; there was only slight proteinuria. He returned to school until early in 1965, when hypertension, oedema, and uraemia became uncontrolled, and he died in 
March 1965, two years after the onset of his illness. Elastic stains on the post-mortem kidney showed extensive vascular lesions in vessels up to interlobar size, consisting of breaks in the internal elastic lamina, severe loss of media, and fibrointimal proliferation with development of a new internal elastic lamina (Special Plate, Fig. 2). The elastic lesions and medial scarring indicated a previous attack of necrotizing arteritis affecting the kidney.

In summary, acute glomerulonephritis resulted in oliguria for 28 days and required five haemodialyses in five weeks. Maximum recovery of renal function occurred about 12 months after the onset of the illness. He returned to school, but eventually died as a result of hypertension and uraemia two years after the illness began. The histological changes at necropsy were those of healed necrotizing arteritis, indistinguishable from a polyarteritis nodosa.

\section{Case 2}

A 35-year-old office-worker developed a dry cough and pleuritic pain in September 1964. His health gradually improved during the next four weeks, but he was then admitted to hospital elsewhere because a chest radiograph showed a loculated effusion. While he was in hospital he had four small haemoptyses. No acid-fast bacilli were found in or cultured from the sputum, a bronchoscopy showed no abnormality, and at no time was there radiological evidence of intrapulmonary haemorrhage. A muscle biopsy did not disclose any manifestations of polyarteritis. After 28 October he was observed to pass diminishing volumes of urine which contained hyaline and granular casts together with numerous red blood cells, and on 3 November he was transferred to Hammersmith Hospital with a blood urea of $320 \mathrm{mg} . / 100 \mathrm{ml}$.

He appeared wasted and ill, the blood pressure was 100/80, and a pericardial friction rub was audible. Neither the liver nor the spleen was palpable. The haemoglobin was $8.0 \mathrm{~g} . / 100 \mathrm{ml}$., and the white blood count $16,000 / \mathrm{cu}$. mm. (89\% neutrophils). The plasma bicarbonate was $19 \mathrm{mEq} / \mathrm{l}$, but the sodium, potassium, and chloride concentrations were normal. The plasma albumin was reduced (2.1 g. $/ 100 \mathrm{ml}$.) and the globulin was increased $(4.7 \mathrm{~g} . / 100 \mathrm{ml}$.$) ,$ largely as a result of an increase in $\gamma$-globulin. The antistreptolysin titre was normal. A chest radiograph showed that the pleural effusion was clearing and that the heart shadow had increased in size.

Peritoneal dialysis was started on admission and was performed continuously until the uraemia was controlled, then for about 10 hours each day (Pringle and Smith, 1964). Treatment with prednisone $60 \mathrm{mg}$. daily was also begun. For 10 days the daily urine volume only once exceeded $50 \mathrm{ml}$. (Fig. II), and on the fourteenth day of dialysis it first reached $400 \mathrm{ml}$. Daily peritoneal dialysis was performed for a total of four weeks.

A renal biopsy 16 days after admission showed 12 abnormal glomeruli. One was obliterated, the others showed proliferative and mild exudative changes, but the striking lesion was capsular proliferation, which was present in all glomeruli and frequentiy affected the whole circumference. Four glomeruli showed breaks in the basement membrane of Bowman's capsule (Special Plate, Fig. 3). The arterioles and glomeruli showed no fibrinoid. Occasional tubular casts were present. Interstitial inflammation was slight.

He was discharged from hospital in December with a blood urea of $94 \mathrm{mg} . / 100 \mathrm{ml}$. Three weeks after leaving hospital his blood

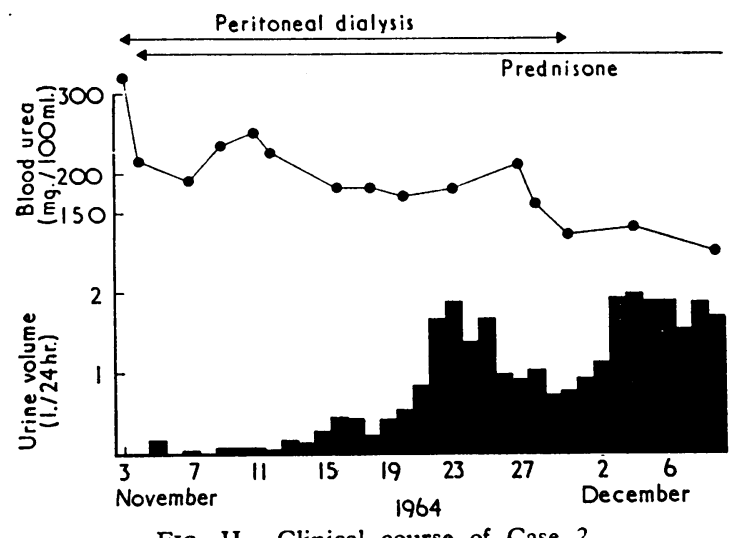

FIG. II-Clinical course of Case 2. pressure, which had been normal in hospital, was found to be $200 / 150$, and it has since been satisfactorily treated. The dose of prednisone was gradually reduced, being finally stopped in June 1965. The plasma protein concentrations and the electrophoretic pattern have returned to normal. In August 1967 the blood urea was $94 \mathrm{mg} . / 100 \mathrm{ml}$. while he took a normal diet, and the 24-hour urinary protein excretion was $1.1 \mathrm{~g}$.

In summary, a patient with acute proliferative glomerulonephritis of unknown cause, who was oliguric for 14 days, recovered after four weeks of peritoneal dialysis. He then had mild renal failure with hypertension which was easily controlled. Three years after his acute illness he was eating an unrestricted diet and was at work.

\section{Case 3}

A 48-year-old housewife was sent to Hammersmith Hospital on 9 April 1965, because oliguria had developed 10 days after a sore throat. In 1948 she had been admitted to hospital elsewhere with a diagnosis of acute glomerulonephritis after an attack of tonsillitis. She was oedematous then, but there was no record of oliguria. Apparently she recovered completely from her renal disease, but there was no record of subsequent urine examinations.

When she was seen here in 1965 the blood pressure was $150 / 90$ and she was oedematous. The haemoglobin was $8.5 \mathrm{~g} .1100 \mathrm{ml}$. and the white blood count $5,000 / \mathrm{cu}$. $\mathrm{mm}$. The blood urea was 315 $\mathrm{mg} . / 100 \mathrm{ml}$. and the plasma electrolyte concentrations were sodium 133, potassium 6.5 , chloride 98 , and bicarbonate $18 \mathrm{mEq} / \mathrm{l}$. There was an increase in the total plasma globulin concentration (3.6 g./ $100 \mathrm{ml}$.), with a particularly high $\gamma$-globulin concentration of $1.8 \mathrm{~g} . /$ $100 \mathrm{ml}$.; the albumin was $2.7 \mathrm{~g} .1100 \mathrm{ml}$. The antistreptolysin titre was 1,200 Todd units $/ \mathrm{ml}$.

Peritoneal dialysis was started at once and continued daily for six weeks (Fig. III). Treatment with prednisone $60 \mathrm{mg}$. daily began on 13 April. A renal biopsy performed on that day showed 18 glomeruli all severely affected by lobular proliferative and exudative

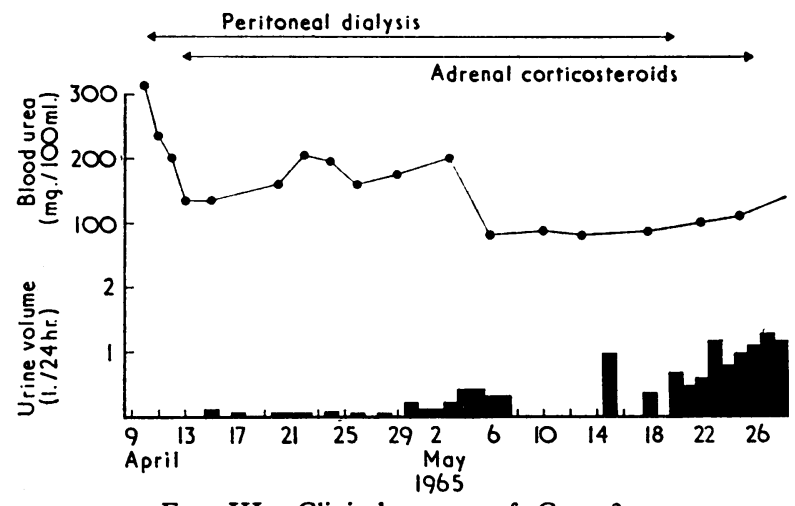

FIG. III.-Clinical course of Case 3 .

changes (Special Plate, Fig. 4). In seven, fibrinoid material was striking, and four arterioles showed fibrinoid change also (Special Plate, Fig. 5). Crescents were seen in four glomeruli. The tubules were normal and interstitial inflammation was slight.

By 5 May she was passing up to $300 \mathrm{ml}$. of urine daily. On account of a Cushingoid appearance and the lack of any evidence that she had benefited from corticosteroid therapy, the dose of prednisone was reduced by $5 \mathrm{mg}$. each day. Three days later, on $8 \mathrm{May}$, on which day she received $40 \mathrm{mg}$. of prednisone, she again became totally anuric and remained so for the next six days. Though it was uncertain whether the anuria had been precipitated by reduction in the dose of prednisone, it was decided on 11 May to increase the corticosteroid dosage. Prednisone was replaced by cortisone acetate $300 \mathrm{mg}$. daily intramuscularly because of vomiting, and the dose was gradually reduced after four days by $50 \mathrm{mg}$. each day. On 20 May she passed $600 \mathrm{ml}$. of urine, and dialysis was stopped. Her urine output increased to over a litre a day, and she gradually became hypertensive.

A second renal biopsy on 18 May, showed some improvement, particularly in the exudative changes. When last seen, in August 1967, her blood pressure (treated) was 160/90 and her blood urea $56 \mathrm{mg} . / 100 \mathrm{ml}$., while she took a normal diet.

In summary, a 48-year-old woman had a second attack of acute post-streptococcal glomerulonephritis. P.enal biopsy revealed a 
severe proliferative glomerulonephritis with fibrinoid degeneration of arterioles. Oliguria persisted for 40 days, during which time she required peritoneal dialysis. Two and a half years later the blood urea was only slightly raised, there was mild proteinuria, and hypertension was easily controlled. She ate an unrestricted diet and lived an active life.

\section{Case 4}

A 15-year-old schoolboy developed diarrhoea, in which a few blood clots were seen on 21 January 1965. The next day he began to vomit, and on the $23 \mathrm{rd}$ he was admitted to another hospital, where he complained of diplopia. The blood pressure was then $170 / 105$, the optic fundi were normal, and no abnormal neurological signs were found. The same evening he became excited and confused, and appeared to be suffering from paranoid delusions. An injection of $50 \mathrm{mg}$. of chlorpromazine was given.

The results of laboratory investigations on the day he was admitted to hospital were haemoglobin $10.8 \mathrm{~g} . / 100 \mathrm{ml}$., white blood count $19,000 / \mathrm{cu}$. mm. ( $88 \%$ neutrophils), and blood urea $240 \mathrm{mg} . / 100$ $\mathrm{ml}$. The cerebrospinal fluid was normal.

On the morning of 24 January his speech was slurred and rambling in content, roving movements of the eyes were noted, and he lapsed into unconsciousness. Because he had been anuric since admission to hospital he was transferred to Hammersmith Hospital on 25 January, where he was found to be unconscious, and to have frequent writhing movements of the upper limbs and attacks of opisthotonos. In the intervals between these attacks the tendon reflexes were brisk, there was trismus and a brisk jaw-jerk, but the plantar responses were flexor. Coarse nystagmus was present in both eyes. The blood pressure was 140/80. Tracheostomy was performed because of difficulty in maintaining an airway, and peritoneal dialysis was begun.

The results of initial laboratory investigations at Hammersmith Hospital were haemoglobin $11.5 \mathrm{~g} . / 100 \mathrm{ml}$., platelets $110,000 /$ cu. mm., white blood count $15,000 /$ cu. mm. ( $90 \%$ neutrophils), blood urea $380 \mathrm{mg} . / 100 \mathrm{ml}$., plasma sodium 140 , potassium 7.0 ., chloride 98 , bicarbonate $17 \mathrm{mEq} / \mathrm{l}$; serum calcium $10.8 \mathrm{mg} . / 100 \mathrm{ml}$., albumin $3.0 \mathrm{~g} .1100 \mathrm{ml}$., and globulin $3.4 \mathrm{~g} .1100 \mathrm{ml}$. ; there was no increase in $\gamma$-globulin. The blood film showed slight red-cell fragmentation only. The antistreptolysin titre was normal. A chest radiograph was normal. No pathogens were cultured from the stool. There was no biochemical evidence of porphyria. A vigorous inquiry was made to identify any possible external poison which could have caused his illness, but none was found.

His neurological condition progressively improved and consciousness returned on 31 January. He was totally anuric for 19 days and daily peritoneal dialysis was required for four weeks (Fig. IV). The blood pressure was normal until peritoneal dialysis was stopped. The platelet count throughout his admission remained between 110,000 and $235,000 / \mathrm{cu}$. $\mathrm{mm}$.

A renal biopsy on 15 February showed an infarcted area of cortex separated by a zone of partial infarction from an area of normal cortex. In the infarcted area the vessels were necrotic, though one vessel (probably an arcuate artery) showed fibrinoid necrosis of part of its wall and thrombus in its lumen. No arteritis was seen. The lesion was thought to be a renal infarct, consistent with a patchy cortical necrosis.

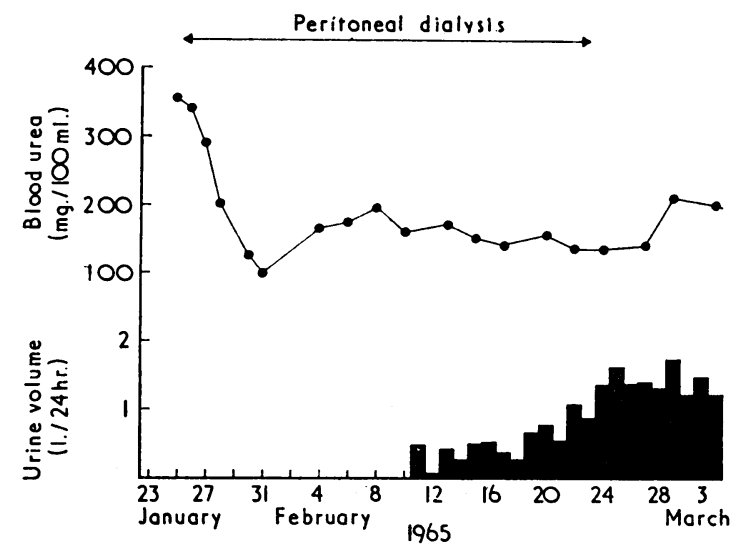

FIG. IV.-Clinical course of Case 4.
He returned to school in May 1965 and has remained in good health. In March 1967 the blood urea was $62 \mathrm{mg} . / 100 \mathrm{ml}$. and the 24 -hour protein excretion was only $0.4 \mathrm{~g}$. The blood pressure was easily controlled. Recent $x$-ray films showed no sign of renal cortical calcification.

He appears to have had an acute diffuse vascular disease similar to the idiopathic illness' reviewed by Campbell and Henderson (1949), a frequent feature of which is renal cortical necrosis. A very similar illness has recently been reported (Baker and Flax, 1967) in a 15-year-old boy: at necropsy multiple irregular cortical infarcts were found with hyaline thrombi occluding glomerular capillaries, afferent arterioles, and terminal interlobular arteries; an extensive search of the brain and other tissues revealed similar vascular lesions in the colon only.

Our patient started to pass urine after 19 days of total anuria, but dialysis was necessary for four weeks. At the time of writing, nearly three years after the onset of his illness, he remained well.

\section{Discussion}

When these four patients were admitted to Hammersmith Hospital their recovery was considered unlikely. Recovery of sufficient renal function to maintain good health after prolonged oliguria in acute glomerulonephritis is rare, though a few cases have been documented (Brod, 1949 ; Harrison et al., 1964 ; Nakamoto et al., 1965 ; Persoff, 1965 ; Lanari et al., 1967). However, it is known that the histological changes of glomerulonephritis may continue to regress for several years after the acute illness (McCluskey and Baldwin, 1963). Clinical improvement may likewise continue for many months, as shown by Case 1 and by the patient of Linder and Bottiglieri (1964), a young man with proliferative glomerulonephritis who, after three months of oliguria, required intermittent peritoneal dialysis for a further nine months before he was able to live without dialysis.

The chance of recovery when oliguria is due to renal cortical necrosis is even smaller, and recovery of patients with histological proof of this condition has only occasionally been reported (Crook, 1927 ; Gormsen et al., 1955 ; Ober et al., 1956 ; Boucot et al., 1957; Lauler and Schreiner, 1958 ; Dérot et al., 1960 ; Vernon-Parry and Williams, 1963 ; Walls et al., 1966).

In Case 1 the presence of polyarteritis, which was suggested but not proved by the renal biopsy, might have been expected to result in an early fatal outcome as the chief cause of early death in polyarteritis is renal failure (Frohnert and Sheps, 1967) and once oliguric renal failure occurs recovery is most unlikely: for example, all the 14 patients of Harrison et al. (1964) with acute oliguric renal failure due to microscopical polyarteritis (Davson et al., 1948) died without any evidence of recovery from their lesions.

In Case 2 it was impossible to prove whether the acute glomerulonephritis was a feature of a generalized vasculitis or not. The glomerular lesions were as severe as those in the fatal glomerulonephritis described and illustrated in eight cases by Berlyne and Baker (1964) and in two cases described by Lee et al. (1966). The most significant differences between Case 2 and these other patients is that Case 2 was treated longer by peritoneal dialysis, and was active and well three years later.

In Case 3 the predominant lesion was proliferation within the glomerular tufts, but in addition fibrinoid material was present in arterioles and in glomerular capillaries. Cases 3 and 4 of Harrison et al. (1964) showed that such lesions may heal by scarring, with recovery of a useful degree of renal function, but Lee et al. (1966) adopted a more pessimistic attitude, taking the view that "a partial diuresis is possible in the presence of severe endothelial proliferation even with focal areas of fibrinoid, although the eventual outcome is fatal." Clearly a more optimistic attitude is justified because this patient, who was oliguric for about 40 days, was in good health more than two years after the acute illness. 
The fourth patient had a bizarre and unexplained illness with features which suggested an acute vascular disturbance affecting the gastrointestinal tract, kidneys, and brain. The association of diarrhoea and renal cortical necrosis in children is well known (Campbell and Henderson, 1949). Necroses may occur in other organs (Duff and Murray, 1941), though evidence of brain involvement is rare apart from convulsions (Baker and Flax, 1967).

Although there is a general correlation between the severity of the histological changes in the kidney, as revealed by renal biopsy, and the prognosis for recovery of renal function, it is clear from these cases that exceptions occur both after glomerulonephritis with prolonged oliguria and after acute cortical necrosis. Exceptions might be due to an unrepresentative sample, and because of this possibility we agree with the view of Lanari et al. (1967) concerning glomerulonephritis, and Vernon-Parry and Williams (1963) in regard to cortical necrosis, that a decision not to treat a patient by repeated dialysis should not be based on a single biopsy specimen. In our opinion there is practically no prospect of significant recovery from acute oliguric glomerulonephritis if all the glomeruli in two consecutive biopsies, each containing at least seven glomeruli, are completely obliterated. In all other cases of glomerulonephritis, particularly those in which patent capillary loops can be seen, we consider that a degree of recovery sufficient to support independent good health is possible and that expectant treatment should be pursued as long as practicable. In renal cortical necrosis, because of the patchy nature of the renal lesion, it is unwise ever to assume on the basis of percutaneous biopsy evidence alone that useful recovery of renal function may not occur.

Awareness is developing that treatment by repeated dialysis is justified in other situations which have hitherto been considered hopeless. Patients have recovered from renal failure complicating nephrotic syndrome after as long as nine months of dialysis (Linder and Bottiglieri, 1964 ; Chamberlain et al., 1966). Four out of five patients who developed oliguric renal failure during the course of a nephrotic syndrome with minimal glomerular lesions have recovered completely from their renal disease, despite uraemic episodes which would undoubtedly have proved fatal without dialysis (Conolly et al., 1968). We have also seen renal recovery from acute renal failure in accelerated hypertension after the blood pressure had been effectively controlled (Sevitt et al., 1968).

Fortunately peritoneal dialysis is now widely available, so that expectant treatment has become a practical proposition, at least for a few weeks or months until peritoneal dialysis becomes technically impossible. Formerly the demand on the limited haemodialysis facilities for the treatment of patients with reversible acute renal failure was so intense that it was not possible to treat by repeated haemodialysis those patients whose chance of recovery seemed slender. Now when peritoneal dialysis fails the patient should ideally be transferred permanently to a chronic intermittent haemodialysis service to await recovery, but if sufficient recovery of function to maintain health without dialysis does not occur then intermittent dialysis may have to be continued indefinitely. Renal transplantation at present has no place in the treatment of patients with active proliferative glomerulonephritis because of the possibility that acute glomerulonephritis will develop in the grafted kidney.

The value of immunosuppressive drugs and adrenal corticosteroids in the treatment of acute proliferative glomerulonephritis is at present not clear except in those cases due to polyarteritis, in which deterioration of renal function can sometimes be slowed or arrested, and rarely reversed by treatment with steroids (Medical Research Council, 1960), though once oliguria had developed Harrison et al. (1964) obtained no improvement with large doses of adrenal corticosteroids. The chance of spontaneous recovery from oliguric polyarteritis is so remote that we suspect that treatment with prednisone contributed to the arrest of the arteritis in Case 1. Cases 2 and 3 provide no definite evidence of response to treatment with. prednisone, but the use of adrenal corticosteroids or immunosuppressive drugs in the treatment of severe glomerulonephritis, either singly or in combination, certainly merits carefully controlled investigation.

\section{Summary}

The recovery is described of four patients with oliguric renal failure lasting up to 40 days: two had severe proliferative glomerulonephritis, one had a necrotizing arteritis, and one had acute renal cortical necrosis.

Useful recovery of renal function cannot be excluded on the evidence of a single renal biopsy specimen.

The outlook in regard to patients with acute renal failure due to severe glomerulonephritis or renal cortical necrosis should be more optimistic than that generally adopted. Suffcient renal function to maintain life may return even after weeks or months of dialysis.

We are grateful to Dr. J. C. Burne for the post-mortem histology of Case 1 and to Professor R. Shackman for the haemodialyses of Case 1.

\section{REFERENCES}

Alwall, N., Erlanson, P., Tornberg, A., Fajers, C.-M., and Moëll, $\mathbf{H}$. (1958). Acta med. scand., 161, 85.

Baker, G. P., and Flax, M H. (1967). New Engl. 7. Med., 277, 536.

Berlyne, G. M., and Baker, S. B. de C. (1964). Quart. f. Med., 33, 105. Boucot, N. G., Guild, W. R., and Merrill, J. P. (1957). New Engl. Y. Med., 257, 416.

Brod, J. (1949). Amer. f. Med., 7, 317.

Brun, C., Gormsen, H., Hilden, T., Iversen, P., and Raaschou, F. (1958). Acta med. scand., 160, 155.

Campbell, A. C. P., and Henderson, J. L. (1949). Arch. Dis. Childh., 24, 269. Chamberlain, M. J., Pringle, A., and Wrong, O. M. (1966). Quart. 3.
Med., 35, 215.

Conolly, M. E., Wrong, O. M., and Jones, N. F. (1968). Lancet, 1, 665. Crook, A. (1927). Proc. roy. Soc. Med., 20, 1249.

Davson, J., Ball, J., and Platt, R. (1948). Quart. f. Med., 17, 175.

Dérot, M., Prunier, P., Roudier, R., and Prunier, Mme. (1960). Bull. Soc. méd. Hôp. Paris, 76, 812.

Duff, G. L., and Murray, E. G. D. (1941). Amer. f. med. Sci., 201, 428.

Forland, M., Jones, R E., Easterling, R. E., and Forrester, R. H. (1966). f. chron. Dis., 19, 163.

Frohnert, P. P., and Sheps, S. G. (1967). Amer. F. Med., 43, 8.

Gormsen, H., Iversen, P., and Raaschou, F. (1955). Amer. F. Med., 19, 209. Harrison, C. V., Loughridge, L. W., and Milne, M. D. (1964). Quart. J.
Med., 33, 39.

Hutt, M. S. R., Pinniger, J. L., and de Wardener, H. E. (1958). Quart. F. Med., 27, 265.

Lauler, D. P., and Schreiner, G. E. (1958). Amer. F. Med., 24, 519.

Lanari, A., Paz, R. A., and Rodo, J. E. (1967). Medicina (B. Aires), 27, 1. Lee, H. A., Stirling, G., and Sharpstone, P. (1966). Brit. med. F., 2, 1361. Linder, W. R., and Bottiglieri, N. G. (1964). Arch. intern. Med., 113,

McCluskey, R. T., and Baldwin, D. S. (1963). Amer. F. Med., 35, 213.

Medical Research Council (1960). Brit. med. f., 1, 1399.

Merrill, J. P. (1957). f. chron. Dis., 5, 138.

Nakamoto, S., Dunea, G., Kolff, W. J., and McCormack, L. J. (1965). Ann. intern. Med., 63, 359.

Ober, W. E., Reid, D. E., Romney, S. L., and Merrill, J. P. (1956). Amer. f. Med., 21, 781 .

Parsons, F. M., and McCracken, B. H. (1959). Brit. med. F., 1, 740.

Persoff, D. (1965). Lancet, 1, 347.

Pringle, A., and Smith, E. K. M. (1964). Brit. F. Urol., 36, 493.

Schreiner, G. E. (1960). Clin. Res., 8, 233.

Sevitt, L. H., Evans, D. J., and Wrong, O. M. (1968). In preparation.

Vernon-Parry, J., and Williams, R. T. (1963). Brit. med. f., 2, 903.

Walls, J., Redman, D., Elliott, R. W., and Kerr, D. N. S. (1966). Proceedings of Third European Dialysis and Transplant Association, Excerpta Medica International Congress Series No. 131, vol. 3, 349. 


\section{A. D. PERRETT ET $A L$. : CROHN'S DISEASE AND CARCINOMA OF COLON}

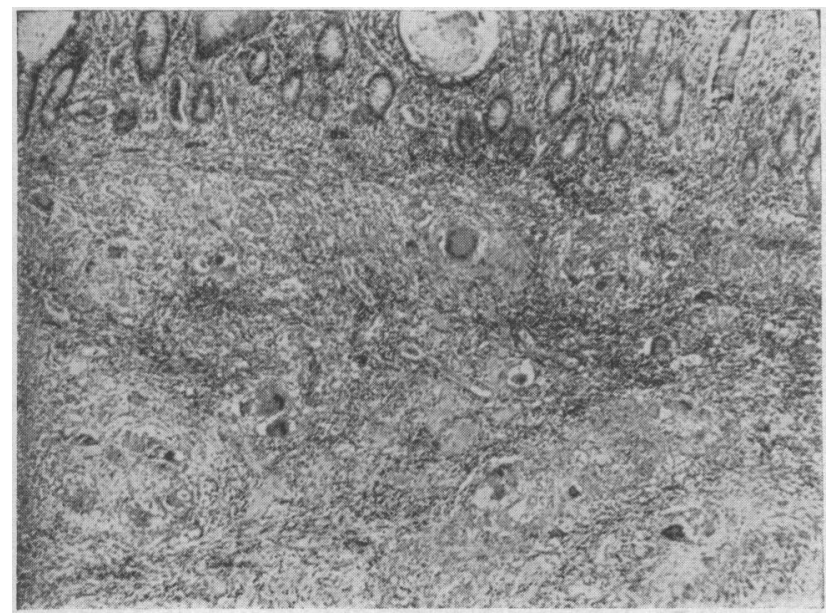

Fig. 7.-Case 3. Heavy inflammatory infiltrate, submucosal thickening, and profuse epithelioid granulomata in the bowel wall.

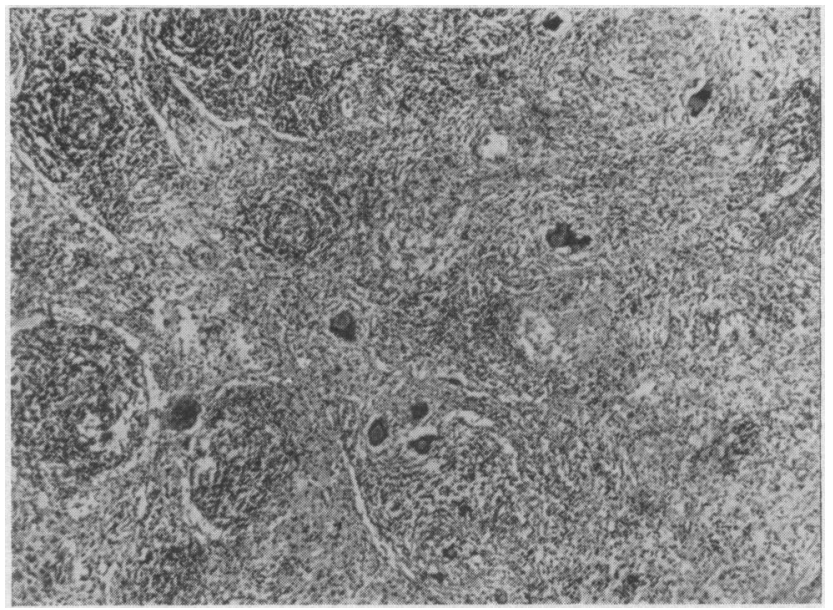

Fig. 8.-Case 3. Lymph node showing profuse granulomata and disorganized architecture.

\section{P. RICHARDS ET $A L .:$ RECOVERY FROM ACUTE RENAL FAILURE}
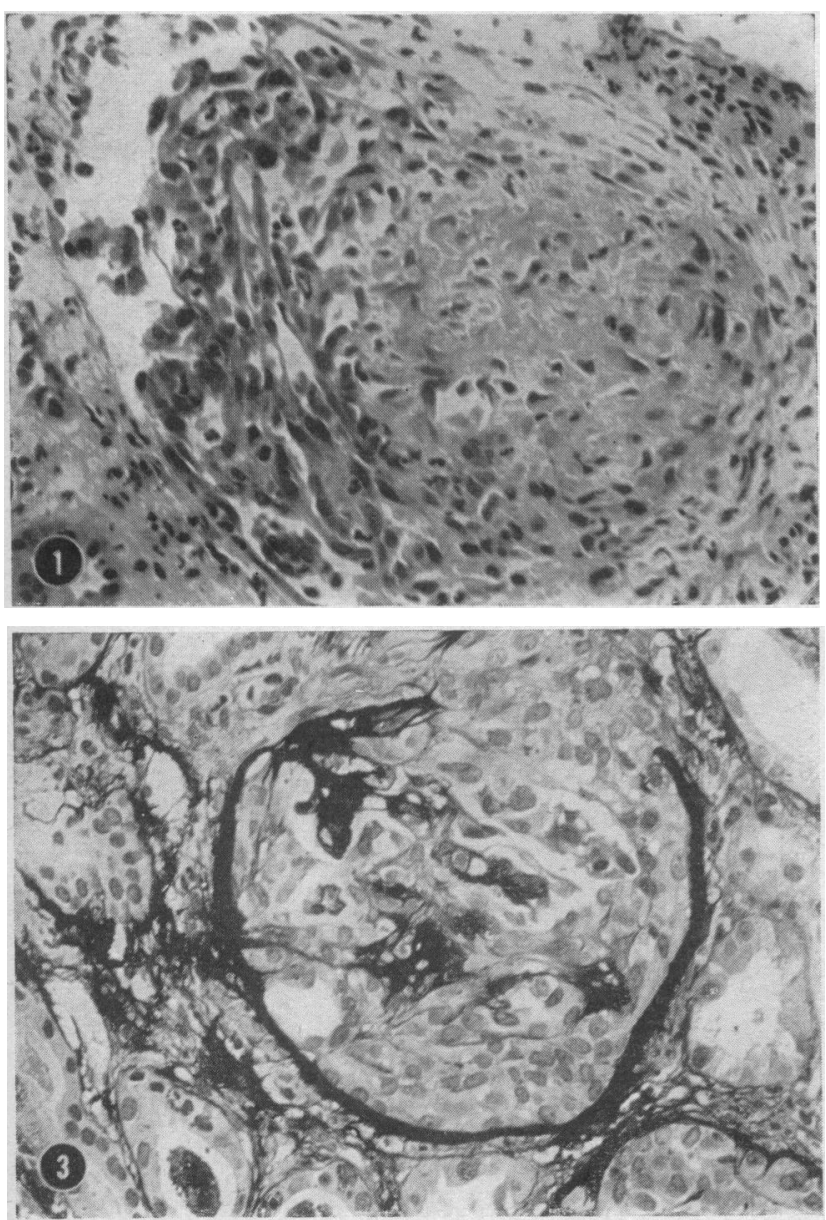

FIg. 1.-Case 1. Glomerulus showing a totally disorganized area A few capillary loops showing proliferation and a polymorph exudate are present on left side of picture. (H. and $\mathrm{E}$. $\times 288$.)

FIg. 2.-Case 1. Interlobar artery from kidney at necropsy, showing break in elastic lamina. (Elastic van Gieson. $\times 72$.)

Fig. 3.-Case 2. Disorganized glomerulus. The intensely black areas are remnants of basement membrane. There is an extensive proliferative capsulitis with a break in Bowman's capsule. (Periodicacid silver methenamine. $\times 288$.)

Fig. 4.-Case 3. Severe proliferative and exudative glomerulitis. (Periodic-acid Schiff. $\times 288$.)

Fig. 5.-Case 3. One of the capillary tufts (arrowed) showing an area of fibrinoid necrosis. (Periodic-acid silver methenamine.
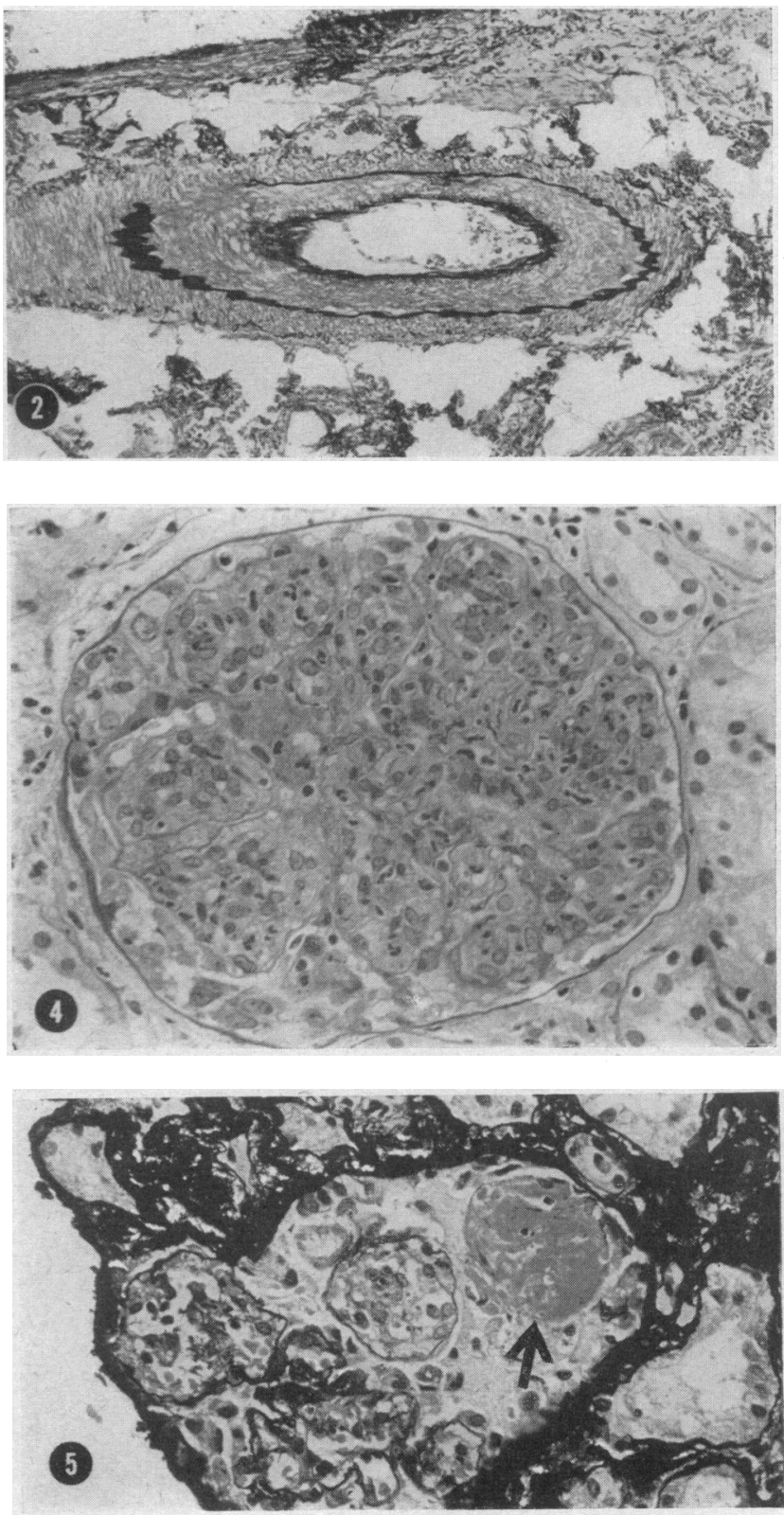